\title{
Abnormalities of insulin and growth hormone secretion in children with coeliac disease
}

\author{
GILLIAN DAY, KENNETH EVANS, and BRIAN WHARTON \\ From Queen Elizabeth Hospital for Children and Institute of Child Health, London
}

\begin{abstract}
Day, G., Evans, K., and Wharton, B. (1973). Archives of Disease in Childhood, 48, 41. Abnormalities of insulin and growth hormone secretion in children with coeliac disease. The effect of intravenous tolbutamide on plasma levels of glucose, cortisol, growth hormone, and insulin, and the effect of oral Bovril on plasma growth hormone have been studied in 10 children with coeliac disease and 6 children who, though small, had normal jejunal morphology ('controls').

The growth hormone and insulin responses to tolbutamide in the children with coeliac disease were significantly smaller than in the controls. Growth hormone response to Bovril was normal in most of the children but 3 of them with coeliac disease failed to achieve a satisfactory response in growth hormone levels after both tolbutamide and Bovril.

These results cannot be explained by malnutrition or by inadequate hypoglycaemia during tolbutamide stimulation, and a convincing hypothesis to explain them has not been formulated. Clinically, though tests of other conventional stimuli of growth hormone and insulin production require study, the diagnosis of coeliac disease should actively be considered in any child with low levels of insulin and growth hormone. These observations may partly explain the association of coeliac disease and diabetes mellitus.
\end{abstract}

In recent years the interactions of the gastrointestinal and endocrine systems have been increasingly studied (Catt, 1970). Since the assessment of small stature may involve investigation of both gastrointestinal and endocrine function in the same child, this clinical situation allows further study of the relations between the two systems.

This paper reports the results of blood glucose, growth hormone, insulin, and cortisol investigations in children with coeliac disease and discusses the clinical and physiological implications of the observations.

\section{Methods}

Sixteen children with small stature and/or signs suggestive of coeliac disease were investigated while still eating a gluten-containing diet. In each child a jejunal biopsy was performed using a Crosby capsule and the responses to oral Bovril and intravenous tolbutamide studied.

The children have been divided into 2 groups: (a) 10 children with coeliac disease, as shown by subtotal villous atrophy of the jejunal mucosa, and a growth spurt after elimination of gluten from diet, and (b) 6 controls with normal jejunal mucosa in whom small

Received 25 May 1972. stature was subsequently considered to be 'psychosocial' in origin or cryptogenic. We considered that only children known to have normal jejunal morphology could act as adequate controls. Table I shows the brief clinical details of these two groups of children. Plasma protein levels were normal in all children and

TABLE I

Clinical features and jejunal morphology of the 16 children investigated

\begin{tabular}{|c|c|c|}
\hline & \multirow{2}{*}{ Normal } & Jejunal morphology \\
\hline & & $\begin{array}{c}\text { Subtotal } \\
\text { villous atrophy }\end{array}$ \\
\hline No. & 6 & 10 \\
\hline $\begin{array}{c}\text { Age (yr) } \\
\text { Mean } \\
\text { Range }\end{array}$ & $\begin{array}{c}6 \cdot 95 \\
2 \cdot 5-11 \cdot 42\end{array}$ & $\begin{array}{c}4 \cdot 45 \\
0 \cdot 58-11 \cdot 67\end{array}$ \\
\hline $\begin{array}{l}\text { Weight } \\
<10 \text { th centile }\end{array}$ & 4 & 4 \\
\hline $\begin{array}{l}\text { Height } \\
<10 \text { th centile }\end{array}$ & 4 & 2 \\
\hline Abdominal distension & $\mathbf{0}$ & 6 \\
\hline
\end{tabular}


there was no clinical, biochemical, or radiological evidence of rickets in any.

Oral Bovril $0.5 \mathrm{~g} / \mathrm{kg}$ was given after a 10 -hour fast according to the method of Jackson, Grant, and Clayton (1968), and blood (finger prick) collected every 15 minutes for $2 \frac{1}{2}$ hours for growth hormone estimation (Greenwood, Hunter, and Glover, 1963). Intravenous tolbutamide $(25 \mathrm{mg} / \mathrm{kg}$ ) was given after a 10-hour fast according to the method described by Marks and Rose (1965) and blood (finger prick) collected at 0, 5, 15, $30,45,60,90,120,150$, and 180 minutes for estimation of growth hormone (Greenwood et al., 1963), insulin (Morgan and Lazarow, 1963), cortisol (Murphy, 1967), and glucose (Morley, Dawson, and Marks, 1968). The growth hormone standard used was an international reference preparation donated by the World Health Organization. The methods used detect down to 1 $\mu$ IU growth hormone, $1 \mu \mathrm{U} / \mathrm{ml}$ insulin, and $0.5 \mu$ $\mathrm{g} / 100 \mathrm{ml}$ cortisol.

\section{Results}

Group results after tolbutamide and Bovril. Table II shows the changes in plasma levels of glucose, cortisol, insulin, and growth hormone after intravenous tolbutamide, and in growth hormone after oral Bovril. The mean values are plotted in Fig. 1.

After tolbutamide the changes in both growth hormone and insulin levels in the children with coeliac disease were significantly smaller than in the control group. After Bovril the growth hormone levels in the 2 groups were similar, though the rise occurred later in the control group.

Maximal levels in individual children. Fig. 2 compares the peak growth hormone level with the peak insulin level in the same child after tolbutamide and also with the peak growth hormone level after Bovril.

In the children with coeliac disease the maximum growth hormone levels were significantly higher after Bovril than after tolbutamide (paired ' $t$ ' test $P<0.001)$, whereas in the control children the maximal levels in both tests were similar. Three children with coeliac disease had maximum growth hormone levels below $15 \mu \mathrm{I}$ units/ml after both stimuli, i.e. levels at which 'partial growth hormone deficiency' might be considered.

TABLE

Effect of intravenous tolbutamide on plasma levels of glucose, cortisol, insulin, and growth hormone, and of orab,

\begin{tabular}{|c|c|c|c|c|}
\hline \multirow{2}{*}{ Metabolite or hormone } & \multirow{2}{*}{$\begin{array}{l}\text { No. of } \\
\text { children } \\
\text { studied }\end{array}$} & \multicolumn{3}{|c|}{ Plasma concentrations } \\
\hline & & 0 & 5 & \\
\hline $\begin{array}{l}\text { Glucose }(\mathrm{mg} / 100 \mathrm{ml}) \\
\text { Coeliac } \\
\text { Control } \\
\text { Statistical significance }\end{array}$ & $\begin{array}{r}10 \\
6\end{array}$ & $\begin{array}{l}58(40-79) \\
68(42-88) \\
\mathrm{NS}\end{array}$ & $\begin{array}{l}52(28-80) \\
63(36-94) \\
\text { NS }\end{array}$ & \\
\hline $\begin{array}{l}\text { Glucose (\% of fasting level) } \\
\text { Coeliac } \\
\text { Control } \\
\text { Statistical significance }\end{array}$ & $\begin{array}{r}10 \\
6\end{array}$ & $\begin{array}{l}100 \\
100 \\
\text { NS }\end{array}$ & $\begin{array}{l}89(65-105) \\
91(67-107) \\
\text { NS }\end{array}$ & \\
\hline $\begin{array}{l}\text { Cortisol }(\mu \mathrm{g} / 100 \mathrm{ml}) \\
\text { Coeliac } \\
\text { Control } \\
\text { Statistical significance }\end{array}$ & $\begin{array}{r}10 \\
6\end{array}$ & $\begin{array}{l}14(8-23) \\
12(6-17) \\
P=0.07\end{array}$ & & \\
\hline $\begin{array}{l}\text { Insulin }(\mu \text { units } / \mathrm{ml}) \\
\text { Coeliac } \\
\text { Control } \\
\text { Statistical significance }\end{array}$ & $\begin{array}{l}8 \\
6\end{array}$ & $\begin{array}{l}5(2-11) \\
6(3-10) \\
\text { NS }\end{array}$ & $\begin{array}{l}22(10-43) \\
45(23-90) \\
P<0.05\end{array}$ & \\
\hline \multirow[t]{3}{*}{$\begin{array}{l}\text { Growth hormone }(\mu \mathrm{IU} / \mathrm{ml}) \\
\quad \text { Coeliac } \\
\text { Control } \\
\text { Statistical significance }\end{array}$} & $\begin{array}{r}10 \\
6\end{array}$ & $\begin{aligned} 9(2-15) \\
10(4-17) \\
\text { NS }\end{aligned}$ & & \\
\hline & & \multicolumn{3}{|c|}{ Plasma concentrations } \\
\hline & & 0 & 5 & \\
\hline $\begin{array}{l}\text { Growth hormone }(\mu \mathrm{IU} / \mathrm{ml}) \\
\text { Coeliac } \\
\text { Control } \\
\text { Statistical significance }\end{array}$ & $\begin{array}{r}10 \\
6\end{array}$ & $\begin{array}{l}7(1-50) \\
6(3-12) \\
\text { NS }\end{array}$ & & \\
\hline NS, not significant. & & & & \\
\hline
\end{tabular}


Comparison of growth hormone and insulin levels after tolbutamide showed that 5 of the children with coeliac disease had low levels of both growth hormone and insulin $(P<0.05)$.

\section{Discussion}

Pathophysiology. Two points require explanation: the reduced insulin and growth hormone response to tolbutamide in children with coeliac disease, and the significantly greater growth hormone response to Bovril than to tolbutamide.

The reduced insulin and growth hormone responses are not due to malnutrition since many of the children with coeliac disease were not malnourished and the results were unlike those occurring in severe malnutrition such as kwashiorkor where, though insulin levels are low, there are raised growth hormone levels (Pimstone et al., 1966; Milner, 1971).

Since the action of parenteral tolbutamide on insulin release is presumably independent of the gut, the cause of the low insulin response to tolbutamide is not clear. We are unable to suggest a convincing hypothesis to explain these observations, but speculations have included a specific effect of gluten on the $\beta$ cells of the pancreas, a nonspecific effect of upper small bowel disease on the pancreas (either directly or via the release of enteroglucagon) (Ketterer et al., 1966) and/or secretin (Dupré et al., 1966), and a possible overlap in the polygenic inheritance of diabetes mellitus and coeliac disease.

Since most of the children with coeliac disease did produce adequate levels of growth hormone after Bovril, the low levels after tolbutamide might merely have reflected the low insulin output during the test failing to achieve sufficient fall in the blood glucose to stimulate growth hormone production. Against this, however, the lowest blood glucose levels reached in the 2 groups were not significantly different whether expressed absolutely or as a percentage of the fasting level (see Table II) and fell within the normally accepted limits (Fajans et al., 1961).

II

Bovril on growth hormone in 10 children with coeliac disease and 6 with normal jejunal morphology ('controls')

(mean and range) at various intervals ( $\mathrm{min})$ after intravenous tolbutamide $(25 \mathrm{mg} / \mathrm{kg}$ )

\begin{tabular}{|c|c|c|c|c|c|}
\hline 15 & 30 & 45 & 60 & 90 & 120 \\
\hline $\begin{array}{c}43(20-72) \\
40(16-65) \\
\text { NS }\end{array}$ & $\begin{array}{c}32(20-72) \\
36(18-52) \\
\text { NS }\end{array}$ & $\begin{array}{c}39(23-62) \\
47(21-74) \\
\text { NS }\end{array}$ & $\begin{array}{c}45(25-70) \\
49(23-80) \\
\text { NS }\end{array}$ & $\begin{array}{c}49(25-72) \\
51(25-76) \\
\text { NS }\end{array}$ & $\begin{array}{c}47(23-72) \\
55(26-85) \\
\text { NS }\end{array}$ \\
\hline $\begin{array}{c}73(47-126) \\
59(28-79) \\
\text { NS }\end{array}$ & $\begin{array}{c}57(34-86) \\
52(34-61) \\
\text { NS }\end{array}$ & $\begin{array}{c}67(44-98) \\
66(39-84) \\
\text { NS }\end{array}$ & $\begin{array}{c}78(53-109) \\
68(43-91) \\
\text { NS }\end{array}$ & $\begin{array}{c}85(55-116) \\
72(47-89) \\
\text { NS }\end{array}$ & $\begin{array}{c}81(58-116) \\
77(52-99) \\
\text { NS }\end{array}$ \\
\hline $\begin{array}{c}21(6-31) \\
19(12-28) \\
\quad N S\end{array}$ & $\begin{array}{c}23(12-30) \\
21(12-32) \\
\text { NS }\end{array}$ & $\begin{array}{c}28(15-42) \\
25(19-27) \\
\text { NS }\end{array}$ & $\begin{array}{c}28(16-41) \\
30(28-35) \\
N S\end{array}$ & $\begin{array}{c}20(14-31) \\
21(10-30) \\
N S\end{array}$ & $\begin{array}{c}16(9-26) \\
16(7-23) \\
N S\end{array}$ \\
\hline $\begin{array}{l}19(8-40) \\
38(18-70) \\
P<0.05\end{array}$ & $\begin{array}{c}9(4-15) \\
13(8-21) \\
\text { NS }\end{array}$ & $\begin{array}{r}8(3-13) \\
11(7-16) \\
\text { NS }\end{array}$ & $\begin{array}{c}7(3-12) \\
10(6-16) \\
\text { NS }\end{array}$ & $\begin{array}{c}5(2-8) \\
10(7-12) \\
P<0.05\end{array}$ & $\begin{array}{l}5(3-11) \\
7(3-11) \\
\text { NS }\end{array}$ \\
\hline $\begin{array}{c}8(2-16) \\
8(3-13) \\
\text { NS }\end{array}$ & $\begin{array}{r}7(2-16) \\
22(7-39) \\
P<0.01\end{array}$ & $\begin{array}{c}9(3-21) \\
18(17-31) \\
P=0.07\end{array}$ & $\begin{array}{c}7(3-17) \\
17(14-20) \\
P<0.001\end{array}$ & $\begin{array}{r}6(3-10) \\
9(7-14) \\
P<0.05\end{array}$ & $\begin{array}{l}7(4-13) \\
7(4-10) \\
\text { NS }\end{array}$ \\
\hline \multicolumn{6}{|c|}{ (mean and range) at various intervals (min) after oral Bovril $(0.5 \mathrm{~g} / \mathrm{kg}$ ) } \\
\hline 15 & 30 & 45 & 60 & 90 & 120 \\
\hline $\begin{array}{c}10(3-30) \\
6(3-11) \\
\text { NS }\end{array}$ & $\begin{array}{c}16(3-65) \\
9(6-15) \\
\text { NS }\end{array}$ & $\begin{array}{c}11(2-25) \\
9(3-24) \\
\text { NS }\end{array}$ & $\begin{array}{c}13(2-35) \\
17(5-37) \\
\text { NS }\end{array}$ & $\begin{array}{r}9(2-18) \\
15(4-33) \\
\text { NS }\end{array}$ & $\begin{array}{c}7(2-21) \\
20(4-50) \\
\text { NS }\end{array}$ \\
\hline
\end{tabular}



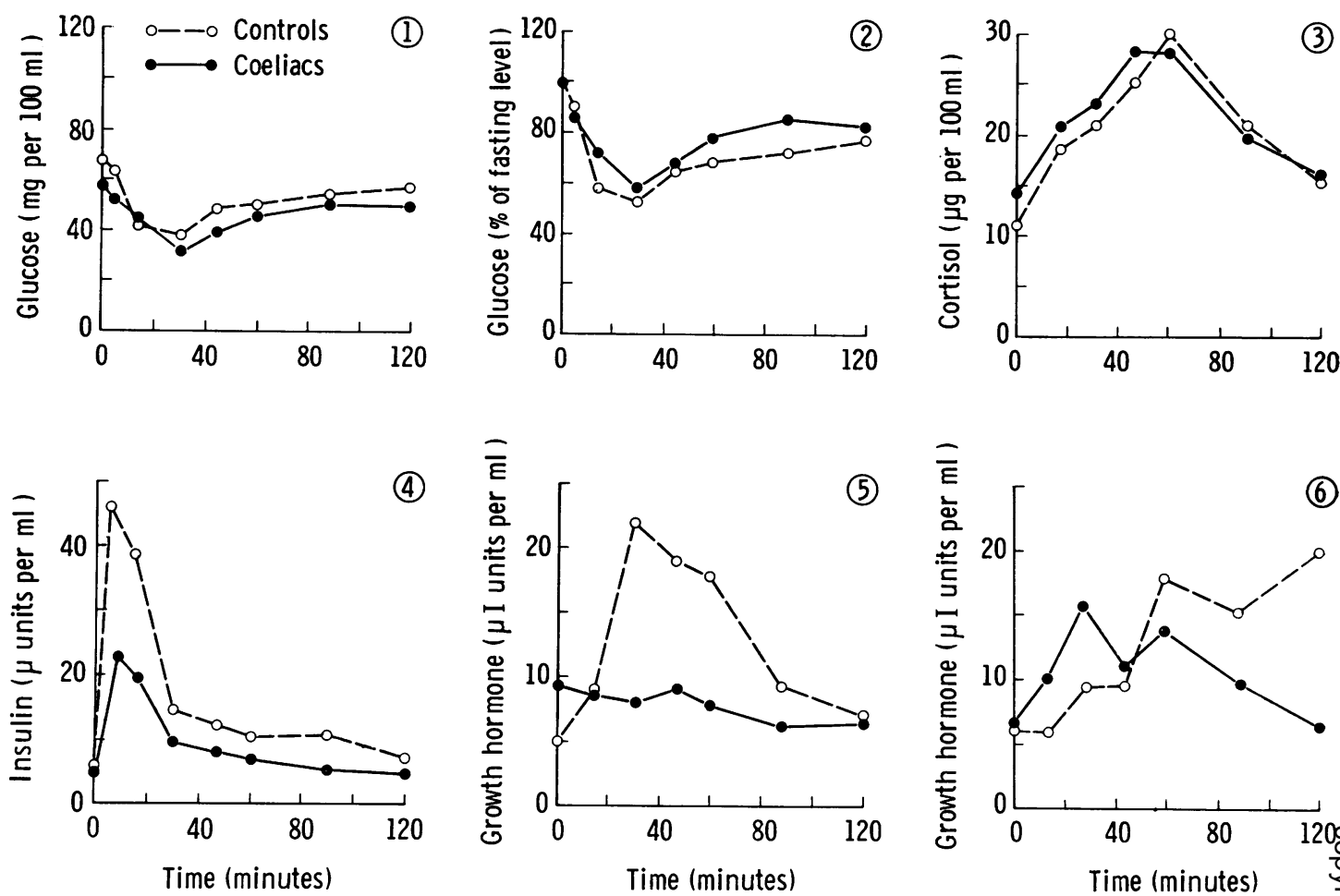

FIG. 1.-Mean values of plasma levels of glucose (1 and 2), cortisol (3), insulin (4), and growth hormone (5) after intravenous tolbutamide, and of plasma growth hormone after Bovril $(6)$ in 10 children with coeliac disease and 6 with normal jejunal morphology.

However, since plasma amino acids after protein loads in both adults and children with coeliac disease are unusually high (Douglas and Booth, 1969; Rossiter, 1973), it may be that children with coeliac disease in this study were receiving a more intense and prolonged stimulus to growth hormone by Bovril than occurs in children with a normal jejunum.

The effect of other endocrine stimulants such as arginine and glucose require study in children with coeliac disease.

Clinical implications. Clearly growth hormone levels in children with short stature and/or failure to thrive must be interpreted with caution.

It seems possible that some children with apparent 'partial growth hormone deficiency' (i.e. peak growth hormone levels of 7-20 $\mu \mathrm{IU} / \mathrm{ml}$-Youlton, Kaplan, and Grumbach, 1969; Tanner et al., 1971), some with low growth hormone production and psychosocial growth failure (Powell, Brasel, and Blizzard, 1967a ; Powell, Raiti, and Blizzard, 1967b), and some 'Group 1 asexual ateliotic dwarfs' (i.e. low insulin and low growth hormone productionMerimee et al., 1969) may in fact have coeliac disease.

This difficulty of diagnosis will particularly apply to small children of school age in whom bowel symptoms may be minimal and steatorrhea absent despite subtotal villous atrophy of the jejunum (Shmerling, Forrer-Durward, and Prader, 1968).

The reduced insulin production of children with coeliac disease, especially as there was little sign of improvement after 9 months on a gluten-free diet in the one child retested, could throw further light on the known association between coeliac disease and diabetes mellitus (Hooft et al., 1968; Birkbeck, N 1969; Hooft, Devos, and van Damme, 1969; Komrower, 1969; Visakorpi, 1969; Walker-Smith and Grigor, 1969; Walker-Smith, 1969), but this possibility would require further investigation.

Dr. T. Savage kindly referred a number of these $\mathbb{D}$ patients to us; Drs. J. F. Ferrier, M. A. Gormley, M. Sanderson, J. R. Williams, and Sister J. M. Wills 


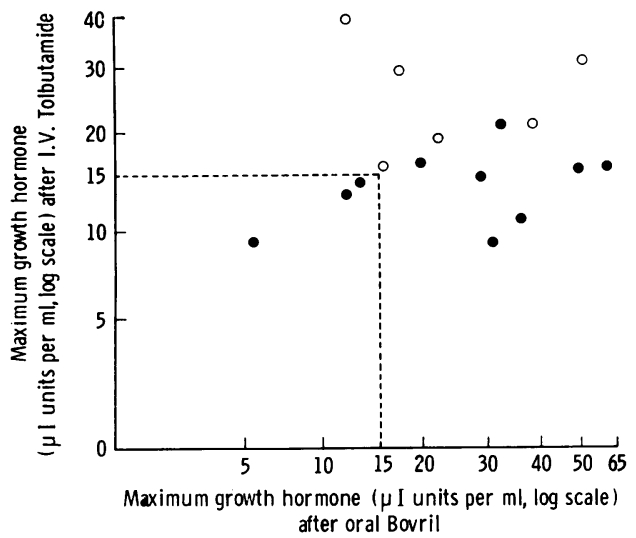

(a)

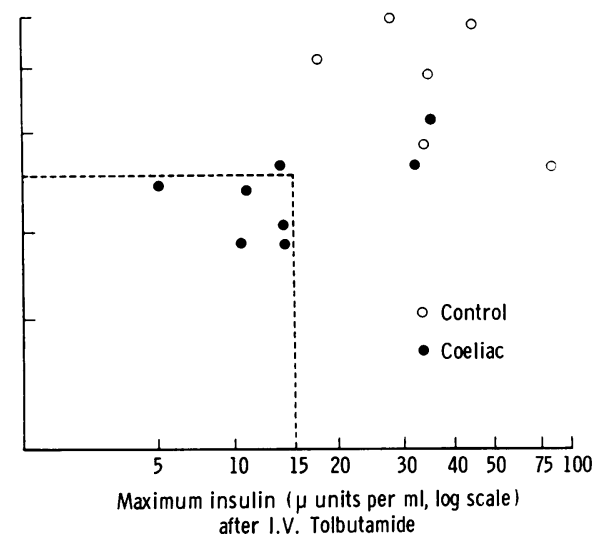

(b)

FIG. 2.-Comparison of the maximum growth hormone level after tolbutamide with the maximum insulin level after tolbutamide and with the maximum level of growth hormone after Bovril in each child.

Note that (a) the maximum growth hormone level in the children with coeliac disease after Bovril (mean highest level $25 \mu \mathrm{IU} / \mathrm{ml}$ ) was significantly higher (paired ' $t$ ' test $P<0.001$ ) than after tolbutamide (mean highest level $14 \mu \mathrm{IU} / \mathrm{ml}$ ), whereas in the controls the maximal levels observed in the 2 tests were similar (mean highest after Bovril $26 \mu \mathrm{IU} / \mathrm{ml}$; mean highest after tolbutamide $26 \mu \mathrm{IU} / \mathrm{ml})$; and $(b)$ the maximum insulin level in the control children after tolbutamide (mean highest level $46 \mu U / m l$ ) was significantly higher (paired ' $t$ ' test $P<0 \cdot 001$ ) than in the coeliac children (mean highest level $19 \mu \mathrm{U} / \mathrm{ml}$ ).

helped in the care of the patients; Miss $\mathrm{H}$. Whittingham and Miss C. Jackson provided secretarial and bibliographical help.

We are grateful to all of them and to the Heinz Research Foundation for their continued support of gastroenterological research at this hospital.

\section{REFERENCES}

Birkbeck, J. A. (1969). Coeliac disease in a diabetic child. Lancet, 2,496

Catt, K. J. (1970). Insulin and glucose homoeostasis. Lancet, $2,353$.

Douglas, A. P., and Booth, C. C. (1969). Post-prandial plasmafree amino acids in adult coeliac disease after oral gluten and albumen. Clinical Science, 37, 643.

Dupré, J., Rojas, L., White, J. J., Unger, R. H., and Beck, J. C. (1966). Effects of secretin on insulin and glucagon in portal and peripheral blood in man. Lancet, 2, 26.

Fajans, S. S., Schneider, J. M., Schteingart, D. E., and Conn, J. W. (1961). The diagnostic value of sodium tolbutamide in hypoglycemic states. Fournal of Clinical Endocrinology and Metabolism, 21, 371.

Greenwood, F. C., Hunter, W. M., and Glover, J. S. (1963). The preparation of ${ }^{131}$ I-labelled human growth hormone of high specific radioactivity. Biochemical fournal, 89, 114.

Hooft, C., Devos, E., and van Damme, J. (1969). Coeliac disease in a diabetic child. Lancet, $2,161$.

Hooft, C., Devos, E., Kriekemans, J., and van Damme, J. (1968). Malabsorption and diabetes mellitus in children. Helvetica Paediatrica Acta, 23, 478.

Jackson, D., Grant, D. B., and Clayton, B. E. (1968). A simple oral test of growth-hormone secretion in children. Lancet, $2,373$.

Ketterer, H., Dupré, J., Eisentraut, A. M., and Unger, R. H. (1966) Insulin-releasing factors of the gastrointestinal tract. (Abst.) Diabetes, 15, 522.

Komrower, G. M. (1969). Coeliac disease in a diabetic child. Lancet, 1, 1215.
Marks, V., and Rose, F. C. (1965). Hypoglycaemia, p. 284. Blackwell, Oxford.

Merimee, T. J., Hall, J. D., Rimoin, D. L., and McKusick, V. A. (1969). A metabolic and hormonal basis for classifying ateliotic dwarfs. Lancet, 1, 963.

Milner, R. D. G. (1971). Metabolic and hormonal responses to glucose and glucagon in patients with infantile malnutriton. Pediatric Research, 5, 33.

Morgan, C. R., and Lazarow, A. (1963). Immunoassay of insulin: two antibody system. Diabetes, 12, 115 .

Morley, G., Dawson, A., and Marks, V. (1968). Manual and autoanalyzer methods for measuring blood glucose using guaiacum and glucose oxidase. Proceedings of Association of Clinical Biochemists, 5, 42.

Murphy, B. E. P. (1967). Some studies of the protein-binding of steroids and their application to routine micro and ultramicro measurement of various steroids in body fluids by competitive protein-binding radioassay. fournal of Clinical Endocrinology and Metabolism, 27, 973.

Pimstone, B. L., Wittmann, W., Hansen, J. D. L., and Murray, P. (1966). Growth hormone and kwashiorkor. Role of protein in growth-hormone homoeostasis. Lancet, $2,779$.

Powell, G. F., Brasel, J. A., and Blizzard, R. M. (1967a). Emotional deprivation and growth retardation simulating idiopathic hypopituitarism. 1. Clinical evaluation of the syndrome. New England fournal of Medicine, 276, 1271.

Powell, G. F., Raiti, S., and Blizzard, R. M. (1967b). Emotional deprivation and growth retardation simulating idiopathic hypopituitarism. II. Endocrinologic evaluation of the syndrome. New England fournal of Medicine, 276, 1279.

Rossiter, M. A. (1973). Metabolic responses to a milk feed in children with coeliac disease. (Abst.) Archives of Disease in Childhood, 48, 79.

Shmerling, D. H., Forrer-Durward, J. C. W., and Prader, A. (1968). Faecal fats in the coeliac syndrome. Lancet, 2, 104.

Tanner, J. M., Whitehouse, R. H., Hughes, P. C. R., and Vince, F. P. (1971). Effect of human growth hormone treatment for 1 to 7 years on growth of 100 children, with growth hormone deficiency, low birthweight, inherited smallness, Turner's syndrome and other complaints. Archives of Disease in Childhood, 46, 745. 
Visakorpi, J. K. (1969). Diabetes and coeliac disease. Lancet, 1, 1192.

Walker-Smith, J. A. (1969). Diabetes and coeliac disease. Lancet, 2,1366 .

Walker-Smith, J. A., and Grigor, W. (1969). Coeliac disease in a diabetic child. Lancet, 1, 1021.

Youlton, R., Kaplan, S. L., and Grumbach, M. M. (1969). Growth and growth hormone. IV. Limitations of the growth hormone response to insulin and arginine and of the immunoreactive insulin response to arginine in the assessment of growth
hormone deficiency in children. Pediatrics, 43, 989.

Correspondence to Dr. Brian Wharton, Queen. Elizabeth Hospital, Hackney Road, London E2. 